\title{
ECONOMIC CRITERIA IN COMPETITION FOR DELIVERIES OF POWER TRANSFORMERS
}

\author{
S. Guseva, N. Breners, N. Skobeleva, H. Vindbergs
}

Riga Technical University, Power Engineering Institute, 1 Kronvalda Blvd., Riga, LV-1010, LATVIA

\begin{abstract}
In the article, economic estimation is given for the measures on purchase of new power transformers and replacement of the existing ones for the Latvian power system (Latvenergo). The optimal choice for the purchases and deliveries of new power transformers is considered as a task of choosing among suppliers on a competitive basis (through tenders). As the objective function for the estimation, the total annual discounted costs for the user of a transformer during its service life are taken. A simplified estimation model is proposed, based on which the calculations of tenders have been done.
\end{abstract}

Key words: high-voltage power transformer, power system (PS), discounted costs, purchases, modernization.

\section{INTRODUCTION}

Reliable and cost-effective operation of high-voltage transformers and regular modernization of their base is a requisite for securing high-quality electricity supply to consumers. The technical condition of a transformer base at slow rates of upgrading and replacement of physically and morally outdated equipment can become the cause of faults and limitations on electricity supply, and even a threat for electric power safety in the state.

Under the market economy conditions, the choice of measures to be taken for updating the electrical equipment in power supply systems should be made based on the technical and economic substantiation of the rational use of monetary resources. Such an approach allows the investments - now limited - in the electric power branch to be reduced by abandoning simultaneous replacement of a big number of the transformers with exhausted normative resource and morally or physically outdated.

In this article, the economic estimation is given for the measures to be taken to purchase new power transformers and replace the existing ones for the Latvian power system (Latvenergo). The optimal choice of the purchases and deliveries of new power transformers is considered as a task of the choice among equipment suppliers on the competitive basis (through tenders). As the objective function for the economic estimation of purchasing and/or replacing transformers we have taken the total annual discounted costs for the users during the service life of a transformer. It should be stressed that the economic estimation of the offers for sale/delivery of transformers has been made only for the variants meeting all the technical requirements for the equipment. 
In a generalized form, the objective function $\left(N P V_{n}\right)$ based on the total annual discounted costs for the users of power transformers in the estimated realization period for a given measure $n$ is:

$$
N P V_{n}=\sum_{t=0}^{T} C_{n T, t} \frac{1}{\left(1+i_{d}\right)^{t}}=C_{n_{O}}+\sum_{t=1}^{T} C_{n T, t} \cdot d_{t},
$$

where $C_{n T, t}$ are the real annual costs (expenses and incomes) for the user of power transformers in the $t$-th year;

$C_{n_{o}}$ are the measure $n$ costs at the beginning of the estimated period;

$d_{t} \quad$ is the discounting factor of costs;

$T \quad$ is the estimated period (service life);

$t \quad$ is the year of the estimated period;

$i_{d} \quad$ is the discount rate.

The basic criterion of a well-founded choice for equipment purchases among supplier companies or manufacturers is the optimal total annual discounted costs (expenses and incomes) $N P V_{n}$ for the user of power transformers in the estimated period.

Identical incomes from the product realization can be excluded from the objective function (Eq. (1)) for the transformers of equal rated power at the comparison of variants. In this case, the costs (expenses) for a user are conditionally assumed to have the positive sign. Thus: opt $N P V_{n}=\min N P V_{n}$.

\section{ESTIMATION OF THE MEASURE ON PURCHASE OF NEW POWER TRANSFORMERS}

The objective function for estimation of a measure $(n=1)$ on transformer purchase and delivery for new objects considering their subsequent operation costs during the normative service life has the form:

$$
\begin{aligned}
& N P V_{1}=C_{1_{o}+} \\
& +\sum_{t=1}^{T}\left\{\begin{array}{l}
\sum_{j=1}^{m}\left[\frac{i}{100} K_{1 T \Sigma, t j}+\frac{1}{100}\left(p_{1 a}+p_{1 r}\right) K_{1 T \Sigma, t j}\right]+ \\
+n_{T}\left[\left(\Delta P_{1_{n l}} T_{t}+\beta_{T}^{2} \Delta P_{1_{s c}} \cdot \tau\right) \beta^{\prime}+\left(\Delta P_{1_{n l}}+\beta_{T}^{2} \Delta P_{1_{s c}}\right) \beta^{\prime \prime}\right.
\end{array}\right\} d_{t},
\end{aligned}
$$

where $C_{1 o}$ are the total costs of measures on new transformer purchase and delivery at the beginning of the estimated period, which are equal to the initial total capital investments in measure $K_{1 T \Sigma}$ (i.e.

$$
\left.C_{1 o}=K_{1 T \Sigma}\right) \text {; }
$$

$j \quad$ is the serial number of the next investment $(j=1, \ldots, m)$;

$K_{1 T \Sigma, t j} \quad$ are the total capital investments into the measures during the $t$-th estimated year considering the $j$-th investment;

$p_{1 a}, p_{1 r} \quad$ are the deductions in percent of the total capital investments in measure $K_{1 T \Sigma}$ on amortization, repair and service; 
$\Delta P_{1 n l}, \Delta P_{1 s c}$ are the no-load and short-circuit losses of the transformer;

$T_{t} \quad$ is the utilization time of a transformer per year;

$\tau \quad$ is the utilization time of the maximum losses per year;

$\beta^{\prime} \quad$ is the cost of $1 \mathrm{\kappa Wh}$ of electric losses;

$\beta^{\prime \prime} \quad$ is the cost of $1 \mathrm{~kW}$ at a power system's maximum;

$\beta_{T} \quad$ is the expected factor of transformer load,

$n_{T} \quad$ is the number of purchased identical transformers;

$T \quad$ is the estimated period (service life of the transformer).

The total capital investments $K_{1 T \Sigma}$ for a given measure at the beginning of

the estimated period can be written as:

$K_{1 T \Sigma}=K_{T}+K_{t r}+K_{i}+K_{s p}+K_{c d}+K_{a d d}$,

where $K_{T}$ is the transformer cost;

$K_{t r}$ is the cost of transportation from a manufacturer to the installation site;

$K_{c d}$ are the customs on the production of a state-supplier;

$K_{s p}$ is the cost of spares (to guarantee the 5-year operation after purchase);

$K_{i} \quad$ is the expected cost of installation;

$K_{\text {add }}$ are additional costs (e.g. of carrying out the reception tests, etc.).

The least total annual discounted costs for the user of power transformers in the estimated period $\left(\min N P V_{1}\right)$ are the basic economic criterion for choosing the winner for equipment delivery among several firms-suppliers/manufacturers.

\section{ESTIMATION OF THE MEASURE ON REPLACEMENT OF AN EXISTING TRANSFORMER}

The necessity to replace an installed power transformer by a new one with improved characteristics (smaller load and no-load losses, lower weight of steel, etc.) can stem from physical or moral obsolescence of the equipment, emergency outage and impossibility to restore the operational condition, mismatch between the rated power and the consumer load, etc.

The given measure $(n=2)$ is a complex one, and is taken at the choice of the power transformer supplier on a competitive basis (through tenders) among supplier-companies/manufacturers, with account for dismantling the operating transformer, the installation of a new one and its further operation during the normative service life.

The search for the optimal decision in this case does not differ much from the task considered above. As in the first case, the objective function includes the purchase and delivery expenses for the new transformer, and, hence, we have here a task of choosing the equipment supplier. At the same time, the objective function should involve additional components - such as dismantling cost $K_{d}$ and liquid 
cost $K_{L}$ of the existing transformer, the cost of installing a new transformer $K_{i}$, i.e.

$$
K_{2 T \Sigma}=\left(K_{1 T \Sigma}-K_{L}\right)+K_{d}+K_{i} .
$$

The liquid cost of transformers at their replacement is defined individually for each transformer and usually does not exceed $10 \%$ of its initial cost.

The objective function (the total annual discounted costs) for the second task is:

$$
\begin{aligned}
& N P V_{2}=C_{2 o}+
\end{aligned}
$$

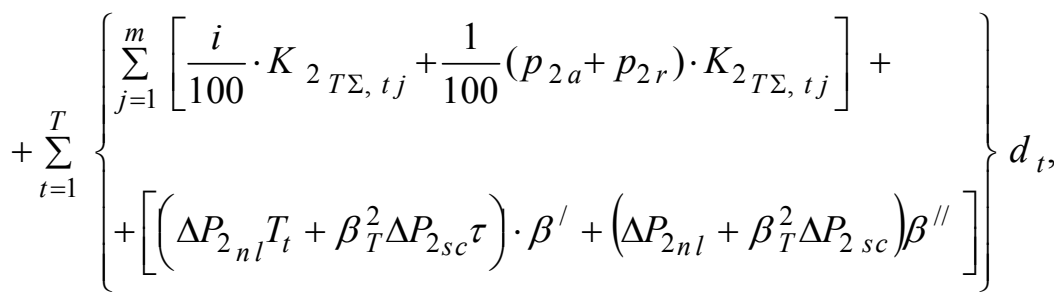

where $C_{2 o}$ are the costs of the measure on purchase and replacement of a transformer at the beginning of the estimated period, which are equal to the initial total capital investments $K_{2 T \Sigma}$.

After the transformer has been replaced, a substantial saving in the operation costs is achieved owing to reduced - in comparison with the replaced transformer - deductions on amortization, operating repair and service; also, a higher reliability of electricity supply is achieved owing to new and more modern equipment.

\section{PRACTICAL CALCULATIONS OF THE TENDER}

Considering the tender on delivery of a $330 \mathrm{kV}$ power transformer (capacity 215 MVA), the total annual discounted costs for the transformer user have been calculated by the proposed method for a substation of the Latvian PS. The variants of transformer delivery from two different firms (called here Manufacturer 1 and Manufacturer 2) were considered. The technical and technically-economic parameters of transformers and networks differ for the examined variants. Besides, there are distinctions between the variants, namely: Manufacturer 1 offers a higher transformer price, while Manufacturer 2 - a lower transformer price, but stipulates a major overhaul of the transformer after 12 years of operation. The overhaul costs are estimated to be $20 \%$ of the transformer cost and referred to the beginning of the estimated period.

The analysis of calculation results shows that variant 1 is more favorable despite the higher price of the transformer (1.3 million EUR in variant 1 and 1.1 million EUR in variant 2). The criterion of the least total annual discounted costs underlies the approach to choosing the firm-supplier between the variants, taking into account differing technical parameters of transformers, their prices, installation and service costs, etc.. A graphic display of the calculation results for 
the total discounted costs in the example under consideration is given in Fig. 1, where it could be seen that by the end of the estimated period ( 25 years) the total discounted costs are the least for variant 1 .

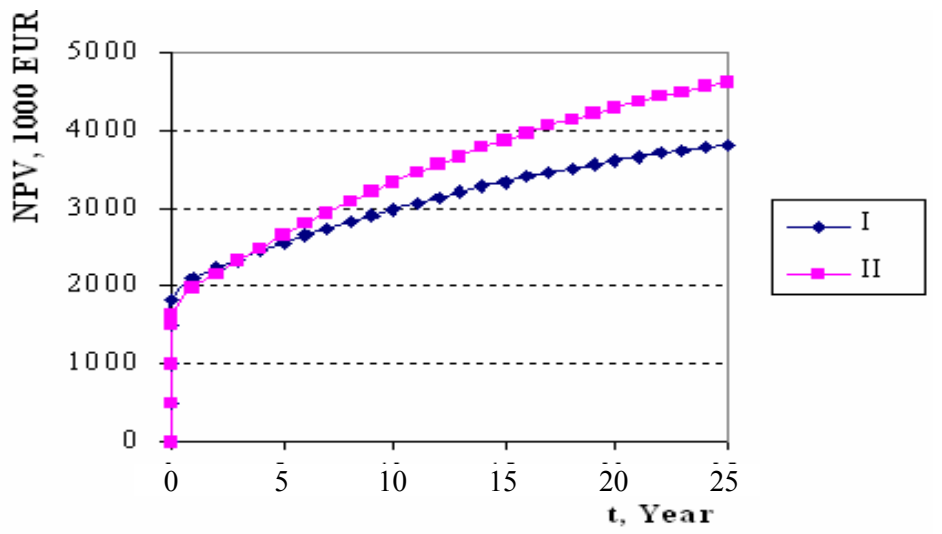

Fig. 1. Comparison of transformer delivery variants.

In the illustrated case the tender for delivery of power transformer is won by the firm-supplier which has offered the conditions of variant 1 .

\section{THE SIMPLIFIED ESTIMATION MODEL FOR CHOICE OF THE EQUIPMENT SUPPLIER}

When preparing a competition of the applicants, it is difficult to estimate precisely the expected operational costs for the transformer during its normative service life. At the same time, when choosing the competition winner it is necessary to consider not only the price of offered transformers and their characteristics, but also the credit terms, the guaranteed service life, the future operational deductions due to power losses, etc. The objective function described by Eq. (2) can be simplified if some assumptions are made for faster estimation of the applicant offers.

We will assume the annual costs for each variant during the estimated period to be constant. If this condition is met and the investments were made at the beginning of the estimated period, formula (1) for measure $n=1$ can be presented as

$$
N P V_{1}=C_{1 T, t} \sum_{t=0}^{T} \frac{1}{\left(1+i_{d}\right)^{t}}=C_{1 o}+C_{1 T, t} \sum_{t=1}^{T} d_{t} .
$$

Considering expressions (6), (2) and having introduced factors $A_{1 k}, A_{1 E c}$, $A_{1 n l}, A_{1 s c}$, we obtain a simplified objective function:

$$
N P V_{1}=C_{1 o}+A_{1 k} K_{1 T \Sigma}+A_{1 E c} K_{1 T \Sigma}+A_{1 n l} \Delta P_{1_{n l}}+A_{1_{s c}} \Delta P_{1_{s c}},
$$

where

$$
A_{1 k}=\frac{i}{100} \sum_{t=1}^{T} d_{t}
$$




$$
\begin{aligned}
& A_{1 E c}=\frac{p_{1 a}+p_{1 r}}{100} \sum_{t=1}^{T} d_{t} \\
& A_{1 n l}=n_{T}\left(\beta^{\prime} T_{t}+\beta^{\prime \prime}\right) \sum_{t=1}^{T} d_{t} ; \\
& A_{1 s c}=n_{T}\left[\beta_{T}^{2}\left(\beta^{\prime} \tau+\beta^{\prime \prime}\right)\right] \sum_{t=1}^{T} d_{t} .
\end{aligned}
$$

Usually, factors $A_{1 k}, A_{1 E c}, A_{1 n l}, A_{1 s c}$ are constant for all applicants within the framework of a particular competition. The introduction of these factors facilitates and accelerates the calculation of $N P V_{1}$ values as well as the final choice of the competition winner. Additionally, a convenient estimation of a specific $N P V_{1 s p}$ value for each competitive variant can be made:

$$
N P V_{1 s p}=\frac{N P V_{1}}{n_{T} S_{\text {Tnom }}},
$$

where $S_{\text {Tnom }}$ is the rated capacity of the delivered transformer.

Table 1

Comparative parameters of the variants

\begin{tabular}{|l|c|c|c|c|}
\hline \multicolumn{1}{|c|}{ Parameters } & Variant 1 & Variant 2 & Variant 3 & Variant 4 \\
\hline No-load losses $\Delta P_{1 n l}, \mathrm{~kW}$ & 28 & 25 & 30 & 27 \\
\hline Short-circuit losses $\Delta P_{1 \mathrm{sc}}, \mathrm{kW}$ & 306 & 225 & 165 & 227 \\
\hline $\begin{array}{l}\text { The price of the transformer, thousand } \\
\text { EUR }\end{array}$ & 669.7 & 821.5 & 806.4 & 711.2 \\
\hline$N P V_{1}$, thousand EUR & 953.0 & 1085.2 & 1062.5 & 970.5 \\
\hline$N P V_{1 s p}$, EUR/kVA & 15.1 & 17.2 & 16.9 & 15.4 \\
\hline
\end{tabular}

Using objective function (7), the calculations for the competition on delivery from different applicants-suppliers of the equipment (namely, $110 \mathrm{\kappa V}-63$ MVA transformers) have been done. The results are tabulated (see Table 1) and presented in Fig. 2.

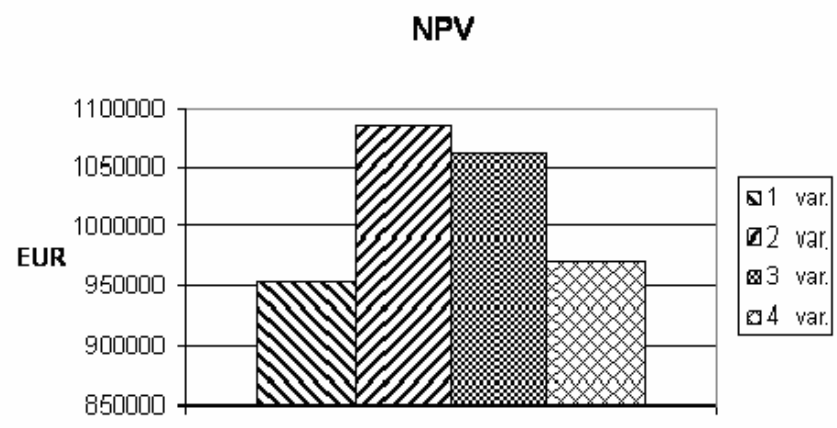

Fig. 2. Comparison of variants for different suppliers. 
According to the results of technical and economic calculations, the competition winner is an applicant who has offered conditions of the first variant, with the least specific total discounted costs.

\section{CONCLUSIONS}

1. The economic substantiation of competitions for delivery of power transformers under market conditions is given.

2. The full and simple objective functions for the cost estimation on delivery and replacement of transformers have been developed based on the total annual discounted costs for the transformer user during the whole estimated period (life cycle of the equipment).

3. The minimum of total annual discounted costs are accepted as a criterion of the optimum choice, which allows a significant number of influential factors to be considered objectively.

4. Practical calculations for tenders on the $330-110 \mathrm{kV}$ power transformer delivery for substations of the Latvian PS have been done using full and simple objective functions.

5. The criterion of the least total annual discounted costs in a competition for deliveries of power transformers is the basic in the approach to choosing the firm-supplier between the variants.

\section{ACKNOWLEDGEMENT}

This work has been supported by the European Social Fund within the National Programme "Support for the development of doctoral and post-doctoral studies" in the framework of the project "Support for the development of doctoral studies at the Riga Technical University".

\section{REFERENCES}

1. Богатов, Б.М., Мейксон, В.Г., Тихонов, А.В., \& Шифрин, Л.Н. (2001). Методика учета стоимости потерь и эксплуатационных расходов в силовых трансформаторах при расчете суммарных годовых затрат у потребителя. Сб. докл. VI Симпозиума "Электротехника 2010", m.2. -Москва: ВЭИ, ТРАВЭК, Россия, с. 40-42.

2. Guseva, S., Mahnitko, A., \& Vindbergs, H. (2005). Economic criteria of an estimation of measures to increase the reliability of transformer equipment functionality. $S c$. proceeding of XII Intern. Sc. Conf. " Present-day problems of power engineering", $A P E^{\prime} 05$, vol.III, Jurata, Hel Peninsula, June 8-10, Poland, pp. 205-212.

3. Breners, N., Guseva, S., \& Kukḷa, N. (2006). Vienkaršots tehniski ekonomiskais modelis augstsprieguma transformatoru nomaiñas novērtējumam. Energétika un elektrotehnika, 4. sērija, 17. sējums, Rīga, RTU, 2006, lpp. 79-84.

4. Гусева, С.А., Бренер, Н.З., \& Скобелева, Н.Н. (2007). Технико-экономическая модель оценки мероприятия по замене силовых высоковольтных трансформаторов. Сб. научн. трудов конф. „Методы и технические средства повышения эффективности применения электроэнергии в сельском хозяйстве”. Ставрополь: Агрус, Россия, с. 209-214.

5. Гусева, С.А., Махнитко, А.Е., Бренер, Н.3., \& Скобелева, Н.Н. (2007). Экономический анализ технических мероприятий по повышению надежности функционирования трансформаторного оборудования. Труды НГТУ им. Р.Е. Алексеева „Актуальные проблемы электроэнергетики”, m.66. -Н. Новгород: НГТУ, Россия, c. $88-92$. 


\section{EKONOMISKIE KRITĒRIJI SPĒKA TRANSFORMATORU PIEGĀDES KONKURSOS}

S. Guseva, N. Breners, N. Skobeleva, H. Vindbergs

Kopsavilkums

Transformatoru iekārtām ir liela nozīme patērētāju drošā apgādē ar elektroenerǵiju. Fiziski un morāli novecojošo transformatoru lēnā nomaiņa var radīt elektroenerğijas piegādes traucējumus vai pat apdraudēt valsts enerǵêtisko drošību. Tirgus ekonomikas apstākḷos visiem tehniskajiem pasākumiem jābūt pamatotiem ar tehniski ekonomiskajiem aprēķiniem naudas resursu racionālai izmantošanai. Darbā piedāvāti tehniski ekonomiskie model̦i, lai novērtētu izmaksas esošo transformatoru nomainai un jaunu transformatoru piegādei. Visparinātā un vienkāršotā modelī ievērotas transformatora lietotāju izmaksas par visu aprēķinu periodu (iekārtas dzīves ciklu). Transformatoru piegādātāju izvēles kritērijs caur konkursa procedūru ir piegādātāja piedāvājums, kurš nodrošina minimālās summārās diskontētās izmaksas transformatora lietotājam par visu aprēķina periodu. Izpildīti piegādātāju piedāvājumu novērtējumi un variantu salīdzinājumi.

17.08.09. 